Jarostaw Michalski*

Toruń

\title{
W kierunku nowego modelu współczesnej edukacji religijnej
}

Współczesne wychowanie religijne oraz dydaktyka religii, podobnie jak wszelka działalność edukacyjna w ciągle zmieniającej się polskiej szkole, podlegają określonym społecznym uwarunkowaniom oraz wyzwaniom postmodernistycznej rzeczywistości. Zasadne zatem wydaje się przedstawienie najbardziej kluczowych i zasadniczych problemów życia społecznego, którym musi sprostać dzisiejsza dydaktyka religii, czy szerzej - proces edukacji religijnej, jeśli chce być skuteczny.

Edukacja religijna, będąc częścią całego procesu edukacji człowieka, nie pozostaje w oderwaniu od konkretnych uwarunkowań społeczno-kulturowych, których cechą charakterystyczną jest obecnie postmodernizm ze swoim relatywizmem i kategorią wielości. Na zasadnicze pytanie: jaka powinna być edukacja religijna, aby mogła oddziaływać na wspótczesnego czlowieka? rodzi się odpowiedź, że skuteczność oddziaływań na każdą epokę jest tym większa, im bardziej się nią żyje. Stąd i edukacja religijna powinna odpowiadać wyzwaniom współczesnego świata, a zwłaszcza powinna być czuła na jego przemiany ${ }^{1}$.

Nauczanie i wychowanie człowieka zawsze dokonuje się w konkretnym kontekście społecznym, kulturowym oraz religijnym. Ta kontekstualność edukacji jest szczególnie ważna w sytuacji edukacji religijnej młodego pokolenia, zwłaszcza że mamy dziś do czynienia z przyspieszeniem przemian, jakim podlega współczesny świat, a wraz z nim człowiek.

${ }^{*}$ Ks. prof. dr hab. Jarosław Michalski jest kierownikiem Katedry Filozofii Wychowania w Wydziale Nauk Pedagogicznych Uniwersytetu Mikołaja Kopernika w Toruniu.

${ }^{1}$ F. Scheitzer, H. Simojoki, Moderne Religionspädagogik, Band 5: Religionspädagogik in pluraler Gesellschaft (RPG), Freiburg-Basel-Wien 2005, s. 237-245. 
W moim przekonaniu istnieją dwie społeczne determinanty współczesnego świata, mające niewątpliwie wpływ na sposób uobecniania się w nim właśnie nauczania religii. Mam tu mianowicie na myśli przede wszystkim kulturę masowej konsumpcji oraz pozostający z nią w ścisłej relacji postmodernizm wraz ze swoim wszechogarniającym relatywizmem².

Kultura masowej konsumpcji ma szczególny wpływ na kształtowanie się postaw i zachowań młodych ludzi. Dostrzega się pod tym względem podstawowe przesunięcie socjalizacyjne i inkulturacyjne, to jest utratę wpływu wychowawczego przez rodzinę, szkołę i Kościół na rzecz kultury masowej (mass media, widowiska, reklama, moda) i wpływów niekontrolowanych grup rówieśniczych. Społeczeństwo otoczone jest przez hiperprzestrzeń kultury popularnej i masowej: wielokanałowa telewizja, dziesiątki kolorowych magazynów, wideo-kino w domu, bogate oferty rynkowe, imprezy masowe i kameralne, światowa sieć informacji komputerowej, erupcja turystyki i migracji, fundamentalizmów i relatywizmów ${ }^{3}$.

Logika rozwoju współczesnej kultury, wyznaczona przez zjawisko nieograniczonej konsumpcji, jest najczęściej nieuporządkowana i spontaniczna. Zdaniem kardynała Pouparda, przewodniczącego Papieskiej Rady Kultury, mamy dziś do czynienia z nowym modelem człowieka „homo-coca-cola”, czyli modelem człowieka zagubionego w specyficznej kulturze masowej konsumpcji ${ }^{4}$. Jednocześnie $\mathrm{w}$ ideologię konsumeryzmu wpisana jest nieodłącznie kategoria niedopełnienia, braku pełni satysfakcji. Współczesny człowiek ciagle poszukuje nowych wrażeń związanych z konsumpcją, ciagle chce „być na czasie”. Dotyczy to w równym stopniu wszystkich podlegających procesowi edukacji, a więc i tych, którzy odbierają ją w powiązaniu z własną konfesją.

Kultura naszego czasu to „kultura typu instant”. Odnosi się ona do typowego dla naszej epoki nawyku i konieczności życia w „natychmiastowości”. Symbolem kultury instant jest słynna triada: fast food, fast sex, fast car. Ten typ kultury wytwarza specyficzną mentalność konsumpcyjna, przystosowująca się do nawyku zmiany, pędu, nieustannego ruchu. Nie ma tu czasu ani możliwości refleksji, kontemplacji rzeczywistości, wejrzenia w siebie, a kontakty międzyludzkie są ulotne bez głębszych zobowiązań i konsekwencji zgodnie z zasadą restauracji fast food: „wchodzę - wychodzę - nigdy

2 S. Kowalczyk, Liberalizm i jego filozofia, Katowice 1995, s. 109-111; J. Karpiński, Kultura i wielość rzeczywistości, Lublin 2002, s. 27-28.

${ }^{3}$ Por. Z. Kwieciński, Mimikra czy sternik? Dramat pedagogiki w sytuacji przesilenia formacyjnego, w: tenże, Tropy - Ślady - Próby. Studia i szkice z pedagogiki pogranicza, Poznań-Olsztyn 2000, s. 37-65.

${ }^{4}$ Między kulturq a antykulturq. Rozmowa $\mathrm{z}$ kard. Paulem Popuardem, przewodniczącym Papieskiej Rady Kultury (rozm. M. Przeciszewski), „Wiadomości KAI“ 29 (2004), s. 24. 
mnie tu nie było". Tworzy się typ człowieka, szczególnie młodego, zorientowanego na „krótkotrwałość”. Typowa dla przeszłości potrzeba wewnętrznej harmonii zostaje przekształcona w poszukiwanie nowości wrażeń ${ }^{5}$.

Tak więc na tożsamość współczesnego człowieka, zwłaszcza młodego pokolenia, znacząco wpływa kultura popularna. Współczesne młode pokolenie jest często nazywane pokoleniem „uwiedzionym przez kulturę masową”. Zastępuje ona niejednokrotnie też rodzinę, szkołę czy Kościół w przekazie wartości. To ona kształtuje dziś kanon lektur i zainteresowań, a także pasji młodego pokolenia, kierunkuje zainteresowania młodzieży ku codzienności, która w realizacji konsumpcji wypiera myślenie o wielkich ideałach, celu życia, jego sensie ${ }^{6}$.

W tej nowej kulturowo sytuacji najlepiej czują się ludzie młodzi. Łatwo przyswajają sobie umiejętności poruszania się w świecie konsumpcji, nowoczesnych mediów. Serena Wiliams, jedna z wybitnych tenisistek amerykanskich, zapytana przez reportera, gdzie czuje się naprawdę dobrze i naprawdę u siebie, odpowiedziała: „Wszędzie tam, gdzie mogę zrealizować moją kartę kredytową". Ten typ mentalności pozwala realizować swoją własną wizję życia jako uczestnictwa w konsumpcji i przeżywać je jako szansę realizowania nieograniczonych możliwości rozwoju. Tożsamość współczesnego nastolatka jest więc $\mathrm{w}$ znacznie mniejszym stopniu kształtowana przez wartości narodowe, patriotyczne czy religijne, a w coraz większym przez kulturę pop oraz ideologię konsumpcji ${ }^{7}$.

Postmodernistyczny relatywizm z kolei uprawomocnia procesy, w toku których religia i jej komponenty (np. wychowanie) tracą wpływ tak na płaszczyźnie instytucji, jak i na płaszczyźnie ludzkiej świadomości. Mamy tu do czynienia nie tyle z procesem emancypacji „świata” spod panowania religii instytucjonalnej, ile raczej z procesem spontanicznej laicyzacji jednostek i całych grup społecznych. Następstwem tego jest między innymi pluralizm, polegający na wielości struktur społecznych i światopoglądów, pozostających we wzajemnej konkurencji pomiędzy sobą. Wiąże się on z wyborem alternatyw, powstałych w sytuacji nowoczesności. Prowadzi to bardzo często z jednej strony do kwestionowania lub negowania obiektywności posłannictwa religijnego, tradycji i autorytetu, z drugiej zaś do wyboru własnego światopoglądu, opartego na subiektywnej opcji, legitymizacji i racjonalności ${ }^{8}$.

${ }^{5}$ Z. Melosik, Tożsamość, ciało i władza. Teksty kulturowe jako (kon)teksty pedagogiczne, Poznań-Toruń 1996, s. 312.

${ }^{6}$ Por. L. Witkowski, Edukacja wobec sporów o (po)nowoczesność, Warszawa 1998, s. $119-120$

7 Z. Melosik, Tożsamość, s. 315.

8 J. Mariański, Moralność w procesie przemian, Warszawa 1990, s. 56. 
Postmodernizm charakteryzuje się również, jeśli chodzi o postawy człowieka, skrajnym sceptycyzmem. O ile dojrzały rozum nadawał sens wszystkiemu, to dla niezdecydowanej myśli postmodernizmu nic już nie ma sensu.

To czas rozbicia i upadku, ciemności i nocy, czas ubóstwa, w którym obojętność staje się śmiertelną chorobą, a słuszne odrzucenie siłowych i totalitarnych perspektyw ideologii doprowadziło do rezygnacji ze stawiania pytania o sens, aż po utratę chęci poszukiwania fundamentalnych racji życia i śmierci człowieka9.

Jednakże, zdaniem J. Habermasa, nie budzi już dziś sporu empiryczny wniosek o tym, że postmodernistyczna wielość będzie bardziej radykalna i że nie ma drogi powrotu do jednolitego społeczeństwa, względnie jednolitej kultury. Zobowiązuje on jednak do poszukiwania zgodności w tejże wielości. W „projekcie modernizmu” Habermas dostrzega powszechną aprobatę postępu cywilizacyjnego oraz niekwestionowaną wartość w postaci rozszerzenia wolności jednostki. $Z$ drugiej strony jednak wskazuje na poważne niebezpieczeństwo szerzenia się wszelkiego rodzaju poglądów fundamentalistycznych oraz neoliberalnych. Fundamentaliści bowiem obstaja przy swoim żądaniu całości, a z kolei zwolennicy neoliberalizmu preferują anything goes (określenie angielskie „wszystko w ruchu”). Jest to, zdaniem Habermasa, z historycznego punktu widzenia przejaw skrajnego cynizmu, wobec którego nie można pozostawać obojętnym na żadnej płaszczyźnie życia, także na płaszczyźnie edukacji religijnej ${ }^{10}$.

Widać zatem, że optymistyczną wizję człowieka, kształtującego w całkowitej wolności swoją historię, upowszechnianą w postmodernizmie, przyćmiewają problemy związane z sensem, a raczej bezsensem życia. Kultura modernistyczna wskazywała na określony sens egzystencji i możliwości samorealizacji. Obecnie, gdy na znaczeniu stracił sens życia określony w tradycji, każdy człowiek staje przed koniecznością samodzielnego znalezienia celu. Relatywizacja systemów wartości, charakterystyczna dla ponowoczesności, utrudnia, a niekiedy wręcz uniemożliwia znalezienie celu i sensu życia. Człowiek w ponowoczesności żyje w atmosferze tymczasowości, a nastawiony na konsumpcję dąży do osiagnięcia pełni satysfakcji przez ucieczkę w to, co łatwe i przyjemne. Skutkiem tego jest rozszerzanie się w wielu przypadkach braku orientacji życiowej. Natomiast przeciwstawną

${ }^{9}$ B. Forte, Chrześcijaństwo europejskie wobec wspótczesnych wyzwań, w: Kościót $w$ życiu publicznym. Teologia polska i europejska wobec nowych wyzwań, t. I, Lublin 2004, s. 17.

10 J. Habermas, Zwischen Naturalismus und Religion. Philosophische Aufsätze, Frankfurt 2005 , s. 279-323. 
tej postawie jest coraz częściej spotykana tendencja „ucieczki w pewność fundamentalizmu" 11 .

Zatem postmodernistyczna wielość jak i kultura konsumpcji stają się istotnym problemem współczesnej dydaktyki religii. Dostrzec jednak można w tych zjawiskach również i szczególne szanse. Myślę tu o uobecnianiu w środowisku szkolnym modelu konfesyjno-komunikatywno-dialogicznego, który stanowić może adekwatną odpowiedź na wielość światopoglądową czasów współczesnych ${ }^{12}$. Zgodnie z tym modelem edukacja religijna stawia sobie wciąż, niezależnie od zewnętrznych uwarunkowań, pytania o sens życia. Mało tego, w edukacji religijnej ze szczególnym naciskiem poszukuje się tego sensu, dziś utraconego z powodu między innymi zjawisk pokrótce wyżej zasygnalizowanych. Przecież we współczesnym społeczeństwie zanika styl życia oparty na refleksji nad życiem i na poszukiwaniu sensu życia. Sama istota takich pytań pozostaje w sprzeczności z podstawowym przekazem społeczeństwa konsumpcji: „ciesz się życiem, kolekcjonuj przyjemności”. Zamiast rozważać ,po co jesteś, sprawdź na wadze, czy nie przytyłaś”"13. W konsekwencji wielkie ideały ustapiły miejsca małym zakupom, poszukiwaniu fascynujących momentów i drobiazgów. Słynna antynomia sformułowana przez Gabriela Marcela: „mieć” czy „być” jest dziś bardzo aktualna. Wydaje się, że współczesna cywilizacja konsumpcji prowadzi człowieka do przekonania, że jedynie posiadanie przyniesie mu szczęście i spełnienie.

Inwazja wszechobecnych w życiu przeciętnego człowieka mediów nie pozwala mu na osobistą refleksję nad ich zawartością, na stawianie pytań o sens, o istotę rzeczy. Zresztą tempo przekazu akcji, rozmaitość obrazów przemieszczanych zgiełkiem szumu informacyjnego, reklamami, wytwarza odbiorcę, który zatraca umiejętność dłuższego skupienia się nad jednym z kadrów. Jak pisze Baudrillard ,jest (wokół nas) coraz więcej informacji a coraz mniej znaczeń" ${ }^{14}$. Prowadzi to do inercji i bezsensu poszukiwań odpowiedzi na podstawowe pytania egzystencjalne.

Pytanie o to, jakie korzyści przynosi lub komu przydatna jest wiedza, która nie jest lub nie może być włączona w całość wspierającą sens życia, pojawia się współcześnie w sposób dość radykalny. Problem ten jest dziś

11 J. Bagrowicz, Edukacja religijna wspótczesnej młodzieży. Źródła i cele, Toruń 2000, s. 192.

12 Por. B. Milerski, Religia a szkoła. Status edukacji religijnej w szkole w ujęciu ewangelickim, Warszawa 1998, s. 213-215.

13 Por. Z. Melosik, Młodzież w kulturze wspótczesnej. Paradoksy pop-tożsamości, w: E. Malewska, B. Śliwerski (red.), Pedagogika i edukacja wobec nowych wspólnot i różnic w jednoczqcej się Europie. Materiaty z IV Ogólnopolskiego Zjazdu Pedagogicznego, Kraków 2002, s. 62.

${ }^{14}$ J. Baudrillard, In the Shadow of the Silent Najorities, New York 1983, s. 95. 
stawiany przez współczesnych, zwłaszcza na terenie pedagogiki. Mówiąc za J. H. Pestalozzim, edukacja oznacza między innymi urzeczywistnienie „człowieczeństwa w człowieku”. To do tej niewątpliwie myśli nawiązywał często Jan Paweł II, gdy istotę wychowania upatrywał w tym, ażeby człowiek stawał się coraz bardziej człowiekiem, ażeby bardziej „,był”, a nie tylko więcej „miał”, aby więc poprzez wszystko, co „ma”, co „posiada”, umiał bardziej i pełniej być człowiekiem - to znaczy ażeby również umiał bardziej „być" nie tylko „z drugim”, ale i „dla drugich”"15.

Zgodnie z tym, zadaniem ,ja" jest stawianie pytań i realizowanie sensu bycia w działaniu, ponieważ ,ja” wspiera ten sens w każdym swoim akcie. Zasadnicza postawa naszej życiowej egzystencji ujawnia się niewątpliwie w stałym zadawaniu pytań o sens naszych wszystkich przedsięwzięć i zamierzeń. Pytania te, niezależnie od tego, czy są wprost sformułowane, czy też pozostają tylko w zamyśle, towarzyszą całemu ludzkiemu życiu ${ }^{16}$.

Pytania o sens pojawiają się szczególnie w kontekście religijności i tu właśnie sytuuje się znacząca rola nauczania religii w kształtowaniu tożsamości jednostek i całych wspólnot społecznych. Człowiek bowiem musi stworzyć dla siebie samego zasadę porządkującą oraz stojące przed nim cele i zadania. Znajduje tutaj zatem swój wyraz potrzeba więzi, sensu, odpowiedzi na tak zwane pytanie religijne. Tu właśnie ma miejsce, jak sądzę, szczególny związek edukacji i religii.

Powróćmy teraz do pytania kluczowego: czy nauczanie religii we współczesnej polskiej szkole ma sens? W jakiejś mierze odpowiedzią na to pytanie były dotychczasowe rozważania. Warto jednak zwrócić uwagę na jeden, moim zdaniem, zasadniczy argument przemawiający za nauczaniem religii we współczesnej rzeczywistości szkolnej. Prawdziwym „dramatem ludzkiego istnienia” jest brak poczucia sensu życia. Dramat ten przejawia się w postaci pustki życiowej jako depresja, brak nadziei i spełnienia. Jednym z głównych zadań edukacyjnych jest więc kształtowanie u wychowanków poczucia sensu egzystencji.

Jak zauważył H. G. Ziebertz, młodzi ludzie pytają o sens egzystencji, który jest dla człowieka „orientacyjną matrycą życia”. W tym miejscu pojawia się doniosłe zadanie dla edukacji religijnej. Trzeba przecież pamiętać, że „nawet wtedy, gdy poszukiwanie sensu nie jest tożsame z religią chrześcijańska, to jednak prowadzi poszukującą osobę przez frontowe drzwi religijnych pytań i doświadczeń" ${ }^{17}$.

${ }^{15}$ K. Wojtyła, Osoba i czyn, Kraków 1994, s. 39.

${ }^{16}$ Por. J. Michalski, Edukacja i religia jakoźródła rozwoju egzystencjalno-kognitywnego. Studium hermeneutyczno-krytyczne, Torun 2003, s. 38.

${ }_{17}$ H. G. Ziebertz, Religionsstile Jugendlicher und moderne Lebenswelt, Freiburg 1996, s. $39 \mathrm{nn}$. 
Jednym $\mathrm{z}$ istotnych elementów uprawomocnienia nauczania religii w szkolnym systemie nauczania i wychowania jest potrzeba i zadanie poważnego potraktowania kategorii aksjologicznych w systemie kształcenia i wychowania. Dlatego też wydaje się, że w sytuacji społeczeństwa ponowoczesnego nauczanie religii, obok kościelnych racji ewangelizacyjnych, nabiera nowego znaczenia.

Pytanie o sens należy do każdego rodzaju nauczania, do każdego przedmiotu nauczanego w szkole. W nauczaniu religii pytanie to nabiera szczególnego znaczenia. Jego zadaniem jest uczyć samodzielnego tworzenia sensu w sytuacji społeczeństwa pluralistycznego. Pytanie o sens ma być więc nie tylko domyślnie obecne, ono ma być osobnym, wydzielonym tematem współczesnej dydaktyki religii „nauczanie religii jest bowiem antropologicznym zadaniem tworzenia sensu", konfrontowania tego sensu z sytuacją egzystencjalną uczniów ${ }^{18}$. Pod tym względem jest to wymóg pedagogiczny, ponieważ uczeń w społeczeństwie pluralistycznym powinien nauczyć się samodzielnego tworzenia własnego sensu i wspólnotowego włączenia się do istniejącej już jego struktur. Pozostaje więc konieczność wyraźnego potraktowania pytania o sens w kategoriach tematu. Szkoła powinna pomóc młodym ludziom w poszukiwaniu własnej tożsamości i stawaniu się coraz bardziej człowiekiem. W kontekście egzystencji ludzkiej jest to umiejętność odpowiedzi na pytania: skąd?, dokąd? i dlaczego? konfrontowanych pod względem religijnym. Nauczanie religii w szkole jest tym polem najbardziej sposobnym i właściwym do stawania pytań o sens egzystencji ${ }^{19}$.

Chrześcijańskie nauczanie religii $\mathrm{w}$ swej istocie i pierwotnym zadaniu podejmuje najpierw pytanie o Boga, który objawił się w Jezusie Chrystusie. Podejmuje następnie ważne pytania o człowieka. Pytania takie są przecież podstawowymi pytaniami pedagogiki Ewangelii, która zachęca człowieka do refleksji nad sobą. Pytanie: „kim jestem”, jest jednym z podstawowych pytań w procesie wychowania. Jeśli jest ono pomijane, wychowanie łatwo może stać się jedynie tresurą lub omijaniem podstawowych zagadnień ludzkiej egzystencji ${ }^{20}$.

${ }^{18}$ Por. M. Nowak, Podstawy pedagogiki otwartej. Ujęcie dynamiczne $w$ inspiracji chrześcijańskiej, Lublin 1999, s. 77-79.

19 Por. V. E. Frankl, Das Leiden am sinnlosen Leben, „Universitas” 2 (1989), s. 154-164; K. Popielski, Neotyczny wymiar osobowości. Psychologiczna analiza poczucia sensu życia, Lublin 1994, s. 187-222; J. Michalski, Sens życia a pedagogika. Impulsy myśli Viktora E. Frankla, Torun 2011, s. 39-47.

${ }^{20}$ R. Chałupniak, Wychowanie religijne czy wychowanie chrześcijańskie?, w: R. Chałupnik, J. Kostorz (red.), Wychowanie religijne u progu trzeciego tysiqclecia chrześcijaństwa, Opole 2001, s. 229. 
We współczesnej dydaktyce religii nie powinno więc chodzić jedynie o to, aby znaleźć gotowe odpowiedzi na pytania, ale o umiejętność stawiania tych pytań i rozumienia siebie samego w ich świetle. Chodzi więc o budzenie pytań natury metafizycznej, ciekawości odnajdywania sensu.

Jak zatem jawi się współczesna edukacja religijna w sytuacji kultury „instant” i jej konsumpcyjnego oblicza. Refleksyjny badacz dopełni tę wątpliwość pytaniem: „w jaki sposób powinni na te zjawiska reagować rodzice i pedagodzy?" Zdaniem Z. Melosika istnieją tu cztery możliwości:

1. świadome dążenie do zablokowania istniejących trendów kulturowych w imię uznanych tradycyjnych wartości kulturowych,

2. bezrefleksyjne dryfowanie wraz z szybko zmieniającą się kulturą,

3. akceptacja euforii supermarketu i bezkrytyczne „klikanie” w rzeczywistość, tak jak gdyby to była strona z Internetu,

4. negocjacja z młodzieżą kształtu rzeczywistości, w której wspólnie żyjemy, a w szczególności kształtowanie w młodzieży nawyku świadomego podejmowania wyborów odnośnie do kształtu własnego ,ja"21. $\mathrm{W}$ przekonaniu autora jedynie czwarta $\mathrm{z}$ wymienionych alternatyw daje pedagogom i pedagogice możliwość realnego uczestnictwa w kształtowaniu tożsamości i życia współczesnej młodzieży.

Nie kwestionując tej opinii, należy jednak zapytać o znaczenie dla edukacji religijnej przynajmniej niektórych elementów jego propozycji. I tak rodzi się wątpliwość dotycząca tego, co może oznaczać „,negocjacja z młodzieżą kształtu rzeczywistości, w której żyjemy"? Nie ulega wątpliwości, że taka negocjacja, jako dialog i zaproszenie do współtworzenia rzeczywistości, jest nieodzowna. Sensem edukacji jest bowiem wzmacnianie twórczych relacji, poprzez które uczeń nabywa odpowiedzialności za rzeczywistość, w której uczestniczy.

Trzeba jednak wyraźnie powiedzieć, jakie elementy rzeczywistości mogą być negocjowane. Zdaniem Waltera Brueggmanna, nauczanie religii powinno najpierw opierać się na kanonie, podlegającym ciagłemu rozwojowi. Tylko wtedy bowiem uniknąć można sytuacji, w której chrześcijańska szkoła albo Kościół jako całość stanie się skansenem niepasującym do potrzeb współczesnego człowieka lub ośrodkiem całkowicie względnymi i oderwanym od tradycji. Sytuacja, w której znajduje się człowiek, wymaga uwzględniania i dialogicznego wspólistnienia zarówno przeszłości, jak i przyszłości ${ }^{22}$.

${ }^{21}$ Z. Melosik, Wychowanie - w którq stronę?, w: Z. Kwieciński, B. Śliwerski (red.), Pedagogika, t. 2, Warszawa 2003, s. 89.

${ }^{22}$ W. Brueggmann, The Creative World. Canon as Model for Biblical Education, Philadelphia 1992, s. 6-13. 
Drugim kamieniem węgielnym współczesnej koncepcji nauczania religii, szczególnie chrześcijańskiej, jest uznanie bezwzględnej wartości każdego człowieka, postrzeganego jako bliźni. Cała mądrość polega na utrzymaniu równowagi, a właściwie dialogu pomiędzy tymi dwoma zasadami naczelnymi: pierwiastkiem boskim i ludzkim w edukacji.

Edukacja religijna powinna ponadto aprobować „uwolnienie”, ale także rozpoznać skutki społeczne tego zjawiska i zapobiegać ucieczce w skrajny indywidualizm. Natomiast niezwykle istotne jest zaakceptowanie umiejętności współczesnej młodzieży w ,podejmowaniu wyborów” i ,prowadzeniu negocjacji”. Chrześcijańska edukacja religijna powinna też, jeśli chce pozostawać skuteczną, pozwolić na rozpoznanie wartości, jaką stanowi indywidualność i okazywać młodym ludziom pomoc w znajdywaniu osobistej równowagi pomiędzy barwną mozaiką własnego ,ja" oraz mocnym rysem własnej osobowości ${ }^{23}$.

I jeszcze jeden istotny moment, ważny szczególnie dziś w sytuacji pluralizmu światopoglądowego. Pedagogika narracji zakłada, że nauczanie religii nie może sprowadzać się jedynie do informacji o możliwych opcjach i rozwiązaniach podejmowanego problemu. Najnowsza koncepcja edukacji religijnej zakłada swoistą drogę środka pomiędzy modelem konfesyjno-katechumenalnym a modelem ponadkonfesyjnym. Osobiście nazywam ją modelem konfesyjno-komunikatywno-dialogicznym, w którym proponuje się odnowę życia uczniów z uwzględnieniem ich elementarnych doświadczeń i pytań. Podkreśla on rangę teorii komunikacji jako naczelnej kategorii współczesnego określania relacji: jednostka-społeczeństwo ${ }^{24}$.

Widzimy więc, że „negocjacja z młodzieżą kształtu rzeczywistości, w której żyjemy" może być także we współczesnej dydaktyce religii przedsięwzięciem twórczym, budującym ich tożsamość i ubogacającym, wnoszącym w przeżywanie wiary doświadczenie życiowe i religijne wszystkich jej uczestników.

Należałoby jeszcze zastanowić się, jak należy rozumieć owo „kształtowanie w młodzieży nawyku świadomego podejmowania wyborów odnośnie do kształtu własnego «ja»"? We współczesnym społeczeństwie zanika styl życia oparty na refleksji nad nim. Sama istota takich pytań stoi w wyraźnej sprzeczności z filozofią społeczeństwa konsumpcji, trudno więc będzie o ,świadome" podejmowanie wyborów. A przecież nie ma wątpliwości, że tylko taka postawa ma sens. Trzeba jednak otwarcie powiedzieć, że świadome podejmowanie wyborów może tylko wtedy być odpowiedzialne i wy-

23 Por. J. Michalski, Wychowanie religijne ,wychodzace od człowieka i zorientowane na człowieka”, „Paedagogia Christiana” 1 (2002), s. 33-49.

24 Por. B. Milerski, dz. cyt., s. 221 nn. 
chowawczo skuteczne, gdy istnieje jakieś jednoznaczne kryterium, trwały fundament, na którym można by się oprzeć, punkt odniesienia dla doraźnych decyzji, które człowiek podejmuje.

Jak wiemy, współczesna pedagogika ucieka od takiego odwoływania się do trwałych zasad. Natomiast pozostaje to wciąż w obszarze zainteresowań edukacji religijnej i tu należy właśnie podkreślać jej znaczenie w kształtowaniu wiary dojrzałej, w kształtowaniu tożsamości jednostek, która przekłada się ostatecznie na kształtowanie tożsamości wspólnoty życia społecznego.

Wspomniany już model konfesyjno-komunikatywno-dialogiczny zakłada kształtowanie wśród młodych ludzi przekonania o religii i religijności jako sile krytycznej, transformującej, konfliktowej, gorącej i uwalniającej. Sugeruje zatem odstapienie od myślenia o niej jako funkcjonalnej, stabilizującej i organizującej. W dzisiejszych czasach przecież większość ludzi znajduje się pod wpływem oddziaływania religii właśnie tego typu. Jednak ten typ prezentuje wyobrażenia fałszywe, które nie tylko nie oddają istoty wiary, lecz również nie wpływają pozytywnie na rozwój tożsamości religijnej młodego człowieka. Będąc wzorcami asymilowanymi w procesach socjalizacji, wyobrażenia ulegają petryfikacji, w wyniku czego świadomość religijna zostaje zafiksowana na poziomie dziecięcym. Ujmując religię funkcjonalnie, neutralizuje się jej działanie, a ona sama, wraz z Bogiem jako strażnikiem prawa i ładu, staje się suchym systemem i stabilizującą wielkością kulturowo-społeczną. We współczesnym kształceniu religijnym chodzi o rewizję takich wyobrażeń ${ }^{25}$.

Należy przy tym podkreślić, że nie jesteśmy w stanie dostatecznie ocenić wkładu dzisiejszej młodzieży w jej usiłowania odnalezienia się w polu napięć, które obecnie istnieje we współczesnym świecie i rozwinięcia w nim pełnej własnej strategii życia. Szkolne nauczanie religii powinno zatem stale mieć na uwadze, że kształcenie w najbardziej ogólnym sensie nie dotyczy jedynie treści fachowych, praktycznych, ale także pomocy w budowaniu sensownego projektu egzystencji młodego pokolenia.

Kończąc powyższe refleksje, których celem było ukazanie wybranych uwarunkowań, prowadzących do konieczności sformułowania współczesnego modelu edukacji religijnej, chciałbym przywołać krótką diagnozę autorstwa K. Ablewicz, dotyczącą współczesnej sytuacji wychowawczej. Sądzę, iż może ona stanowić ważny głos w toczącej się dyskusji na temat koniecz-

${ }^{25}$ Por. W. Piwowarski, Katolicyzm polski jako religijność narodu, w: W. Zdanowicz (red.), Religia i życie społeczne, Poznań-Warszawa 1983, s. 66-82; J. Mariański, Religijność w procesie przemian, Warszawa 1990, s. 32-35; Z. Chlewiński, Religia a osobowość człowieka, w: H. Zimoń (red.) Religia w świecie współczesnym. Zarys problematyki religiologicznej, Lublin 2011 s. 89-105. 
ności i potrzeby właściwej edukacji religijnej w życiu współczesnego człowieka i świata:

Czy uda się konsekwentnie łączyć wiedzę z mądrością w taki sposób, by móc na co dzień realizować cel wychowania i wykształcenia człowieka mądrego, ale i zarazem dobrego swą mądrością? Człowieka, który będzie umiał ową mądrość wyprowadzić nie tylko z wiedzy, ale też z doświadczenia życia codziennego. Być może kryzys pedagogiki współczesnej zbiega się z ekonomiczną wizją człowieka, sprawnego zawodowca, profesjonalisty, który umie rozwiązać zagadki komputerowe i precyzować strategie działań skutecznych, lecz jest zupełnie bezradny i bezsilny wobec trudności spraw ludzkich, pogubiony w priorytetach, gdy los stawia go w sytuacjach granicznych ${ }^{26}$.

\section{Towards a New Model in the Present-Day Religious Education (Summary)}

The logics of present day's culture development has been determined by the unlimited consumption phenomenon; not only does it happen in the Western countries, this has become a frequent occurrence in Central and Eastern Europe's Countries. The logics is disorderly and spontaneous, dominated with the model of man who has lost themselves in the specific "instant" culture, who has not found fulfilment and who is concentrated on experiences' and behaviours' transience. On the one hand this post-modern heterogeneity is accepted, though increasingly radical and without the possibility of return to the homogenous social order or at least a homogenous culture; on the other hand one needs to seek a concordance in this diversity. All kinds of education find their foundations in enhancement of creative relations and social influences; thus the pupil advances in their responsibility for the reality they participate in. The new model of religious education, faced with the present day challenges may become such foundation; this is the place to find answers to the question about the sense of life in the existential dimension, this is the place to shape the habit of making conscious choices regarding the shape of one's I. This article makes an attempt to present this kind of model.

Keywords: religious education; sense of life; conscious choices.

${ }^{26} \mathrm{~K}$. Ablewicz, Teoretyczne $i$ metodologiczne podstawy pedagogiki antropologicznej. Studium sytuacji wychowawczej, Kraków 2003, s. 267. 


\section{W kierunku nowego modelu współczesnej edukacji religijnej (Streszczenie)}

Logika rozwoju współczesnej kultury jest, nie tylko na Zachodzie, ale również i coraz powszechniej w krajach Europy środkowej i wschodniej, wyznaczona przez zjawisko nieograniczonej konsumpcji. Jest ona nieuporządkowana i spontaniczna, w której dominuje model człowieka zagubionego w specyficznej kulturze „instant”, niespełnionego i zorientowanego na krótkotrwałość doznań i zachowań. Aprobując z jednej strony postmodernistyczną wielość, coraz bardziej radykalną z której nie ma już powrotu do jednolitego ładu społecznego i względnie jednolitej kultury, należy dążyć do poszukiwania zgodności w tejże wielości. Fundamentem każdej edukacji jest bowiem wzmacnianie twórczych relacji i wpływów społecznych, poprzez które uczeń nabywa odpowiedzialności za rzeczywistość, w której uczestniczy. Nowy model edukacji religijnej, odpowiadając na wyzwania współczesności, może stać się właśnie takim fundamentem, na którym znajduje się odpowiedź na pytania o sens życia w wymiarze egzystencjalnym, oraz kształtuje w młodzieży nawyk świadomego podejmowania wyborów odnośnie do kształtu własnego ,ja”. Niniejszy artykuł jest próbą przedstawienia propozycji takiego modelu.

Slowa kluczowe: edukacja religijna; sens życia; świadomy wybór. 